\title{
False Seedbeds Reduce Labor Requirements for Weeding in Chile Pepper
}

\author{
Brian J. Schutte ${ }^{1}$, Adriana D. Sanchez ${ }^{1}$, Leslie L. Beck ${ }^{2}$, \\ and Omololu John Idowu ${ }^{2}$
}

\begin{abstract}
Additional index words. Capsicum annuum, chili pepper, cultural weed management, economic value, integrated weed management, seedbank, stale seedbed
\end{abstract}

SUMmARY. This study evaluated false seedbeds, which are sequences of irrigation and tillage that eliminate weed seedlings before crop planting, to reduce requirements for hand hoeing in chile pepper (Capsicum annuum). To address this objective, a field study was conducted near Las Cruces, NM from July 2015 to Oct. 2016 (experimental run 1) and July 2016 to Oct. 2017 (experimental run 2). False seedbeds were designed to target weeds that typically emerge after chile pepper planting. This was done by implementing false seedbeds the summer before chile pepper seeding. During chile pepper seasons, data included repeated measures of weed seedling emergence, amounts of time required for individuals to hoe field sections (i.e., hoeing time), and yields of two chile products: early harvest of green fruit and late harvest of red fruit. Hoeing time and yield data were included in costbenefit analyses that also incorporated expenses and revenues projected by crop budget models for the study region. Results indicated false seedbeds caused a $54 \%$ decrease in weed population density during the chile pepper season of experimental run 1; however, for experimental run 2 , false seedbeds did not affect cumulative weed seedling emergence. For both experimental runs, false seedbeds reduced hoeing times, suggesting that false seedbeds affected hoeing by means other than reduced weed density. After accounting for costs for implementation, false seedbeds reduced hand hoeing costs by $\$ 262 /$ acre to $\$ 440 /$ acre. These reductions in hoeing costs coincided with improved profitability in all but one combination of year and product. Green fruit yield was lower in false seedbed plots in experimental run 1; however, false seedbeds did not affect green fruit yield in experimental run 2, or red fruit yield in both experimental runs. These results indicate that false seedbeds implemented the summer before planting are promising techniques for reducing labor requirements for weeding in chile pepper production.

$\mathrm{I}$

$\mathrm{n}$ the United States, chile peppers (domesticated species within the Capsicum genus) are primarily

Received for publication 8 Sept. 2020. Accepted for publication 30 Nov. 2020.

Published online 7 January 2021

${ }^{1}$ Department of Entomology, Plant Pathology and Weed Science, New Mexico State University, 945 College Drive, Las Cruces, NM 88003

${ }^{2}$ Department of Extension Plant Sciences, New Mexico State University, 945 College Drive, Las Cruces, NM 88003

Funding for this project was provided by the New Mexico Chile Association. Additional salaries and research support were provided by state and federal funds appropriated to the New Mexico State University Agricultural Experiment Station.

We gratefully acknowledge the field assistance of David Duran, Christopher Landau, Ed Morris, Israel Marquez, Taylor Mesman, and Joseph Wood. We thank Jim Libbin and Bradley Tonnessen for reviewing this manuscript.

This article is part of a thesis submitted by Adriana D. Sanchez in fulfilling an M.S. degree requirement.

B.J.S. is the corresponding author. E-mail: bschutte@ nmsu.edu.

This is an open access article distributed under the CC BY-NC-ND license (https://creativecommons.org/ licenses/by-nc-nd/4.0/).

https://doi.org/10.21273/HORTTECH04732-20 produced in California, New Mexico, Arizona, and Texas [U.S. Department of Agriculture, National Agricultural Statistics Service (USDA-NASS), 2020]. Among these states, the economic and cultural impact of chile pepper is perhaps most significant in New Mexico. In a typical year, chile pepper acreage in New Mexico is $\approx 45 \%$ of the U.S. total for this crop, and chile peppers harvested in New Mexico are $\approx 33 \%$ of those harvested in the United States (USDA-NASS, 2020). In 2019, chile peppers were planted on 9100 acres in New Mexico and provided over $\$ 50$ million in cash receipts to farmers in this state (USDA-NASS, 2020). New Mexico chile peppers are grown with irrigation for green fruit and for red fruit. Red fruit are mature green fruit. Green and red fruit are both sold to processors and fresh markets. Chile peppers grown for processing were valued at \$41.4 million in 2019 , and chile peppers for fresh market were valued at $\$ 8.6$ million in 2019 (USDA-NASS, 2020). New Mexico's contribution chile pepper production in the nation reflects, in part, an accumulation of expertise and infrastructure following four centuries of chile pepper cultivation in this state (Bosland, 2015).

Chile pepper production in New Mexico has long relied on human labor for weeding. Labor has become increasingly expensive and is now recognized as a significant threat to the sustainability of chile pepper production in New Mexico (Gandonou and Waliczek, 2013; Hawkes et al., 2008). The need for hand hoeing is caused, in part, by the inability of chile pepper plants to establish competitive advantages over weeds (Amador-Ramirez, 2002), and the long growing seasons for this crop in New Mexico (Bosland and Walker, 2014). New Mexico farmers typically seed chile pepper in March through April, the crop stand is thinned in May through June, and green fruit are generally harvested in August through September. Red fruit are often harvested in October. Throughout this growing season, weeds emerge. If not controlled, weeds reduce yield (Schroeder, 1992, 1993),

\begin{tabular}{llll}
\hline $\begin{array}{l}\text { Units } \\
\begin{array}{l}\text { To convert U.S. to SI, } \\
\text { multiply by }\end{array}\end{array}$ & U.S. unit & SI unit & $\begin{array}{l}\text { To convert SI to U.S., } \\
\text { multiply by }\end{array}$ \\
\hline 0.4047 & $\mathrm{acre}(\mathrm{s})$ & $\mathrm{ha}$ & 2.4711 \\
0.3048 & $\mathrm{ft}$ & $\mathrm{m}$ & 3.2808 \\
0.0929 & $\mathrm{ft}^{2}$ & $\mathrm{~m}^{2}$ & 10.7639 \\
2.54 & inch $(\mathrm{es})$ & $\mathrm{cm}$ & 0.3937 \\
0.4536 & $\mathrm{lb}$ & $\mathrm{kg}$ & 2.2046 \\
1.1209 & $\mathrm{lb} / \mathrm{acre}$ & $\mathrm{kg} \cdot \mathrm{ha}^{-1}$ & 0.8922 \\
1 & $\mathrm{mmho} / \mathrm{cm}$ & $\mathrm{mS} \cdot \mathrm{cm}^{-1}$ & 1 \\
70.0532 & $\mathrm{oz} / \mathrm{acre}$ & $\mathrm{g} \cdot \mathrm{ha}^{-1}$ & 0.0143 \\
1 & $\mathrm{ppm}$ & $\mathrm{mg} \cdot \mathrm{kg}^{-1}$ & 1 \\
0.9072 & $\mathrm{ton}(\mathrm{s})$ & $\mathrm{Mg}$ & 1.1023 \\
0.8361 & yard & $\mathrm{m}$ & 1.1960 \\
$\left({ }^{\circ} \mathrm{F}-32\right) \div 1.8$ & ${ }^{\circ} \mathrm{F}$ & ${ }^{\circ} \mathrm{C}$ & $\left({ }^{\circ} \mathrm{C} \times 1.8\right)+32$
\end{tabular}


reduce harvest efficiency (Schroeder, 1993; Schutte and Cunningham, 2015), and potentially harbor pathogens that are injurious to chile pepper crops (Sanogo et al., 2009, 2013). Herbicides for chile pepper in New Mexico include bensulide, carfentrazone-ethyl, clethodim, clomazone, glyphosate, halosulfuronmethyl, imazosulfuron, napropamide, paraquat, pelargonic acid, pendimethalin, pyraflufen-ethyl, sethoxydim, s-metolachlor, and trifluralin. $\mathrm{Al}$ though these herbicides are effective on many of the weed species that occur in chile pepper fields in New Mexico, weeds that emerge after crop emergence frequently escape chemical control. Weeds between chile pepper rows can be controlled with cultivation; however, cultivation does not affect weeds near or within crop rows. Weeds in crop rows can generally be suppressed with synthetic or natural mulches (Chen et al., 2017); however, mulches are not often used in chile pepper production in New Mexico.

Like all agricultural soils, soils in chile pepper fields contain reservoirs of viable weed seeds (herein called "seedbanks") that enable local persistence of weed populations. High seedbank densities generally increase herbicide dose requirements and frequencies (Dieleman et al., 1999; Hartzler and Roth, 1993; Schutte and Cunningham, 2015), decrease efficacies of mechanical interventions such as cultivation (Davis and Williams, 2007; Dieleman et al., 1999), and increase hand hoeing requirements (Riemens et al., 2007; Schutte and Cunningham, 2015). Recognizing the impacts of seedbank density on weed control outcomes, comprehensive weed management plans feature tactics that aim to reduce the number weed seeds in soil (Swanton et al., 2008).

A method for seedbank reduction that uses commonplace crop production technology is the false seedbed (Cloutier et al., 2007). False seedbeds occur before cash crop planting by first stimulating weed seed germination through tillage and, if necessary, irrigation. Subsequent weed seedlings are then eliminated with shallow tillage. False seedbeds are like stale seedbeds except that stale seedbeds do not use tillage to eliminate weed seedlings that emerge before cash crop planting (Cloutier et al., 2007). By removing germinable weed seeds from upper soil layers, false and stale seedbeds can improve subsequent crop production in several ways: reducing weed densities (Shem-Tov et al., 2006), reducing labor requirements for weeding (Shem-Tov et al., 2006), reducing weed biomass at crop harvest (Caldwell and Mohler, 2001; Lonsbary et al., 2003), increasing crop yield (Johnson and Mullinix, 1995; Johnson and Mullinix, 1998), and increasing profitability (Islam et al., 2009; Lonsbary et al., 2003).

Many weed species in chile pepper feature annual life cycles (Lee and Schroeder, 1995). Because annual weed species are dependent upon seeds for year-to-year persistence, methods for seedbank reduction may improve weed management programs for chile pepper. To our knowledge, false seedbeds have not been systematically evaluated for chile pepper production in New Mexico. The primary objective for this study was to compare economic costs of false seedbed implementation against possible economic benefits derived from reductions in labor requirements for weeding. To accomplish this objective, we determined the false seedbed effects on weed densities, labor requirements for weeding, and fruit yields for chile pepper.

\section{Materials and methods}

STUdY sITE. This study was conducted at the New Mexico State University (NMSU), Leyendecker Plant Science Research Center, Las Cruces, NM (lat. $32.19^{\circ} \mathrm{N}$, long. $\left.106.74^{\circ} \mathrm{W}\right)$. Annual experimental runs occurred from July 2015 to Oct. 2016 (herein named "experimental run 1") and July 2016 to Oct. 2017 (herein named "experimental run 2"). Experimental runs were in different fields, with each field featuring a Belen clay loam [clayey over loamy, montmorillonitic (calcareous), thermic VerticTorrifluvent] One month before the start of the study, fields were subjected to a sequence of preparatory procedures that included tilling, laser leveling, listing, and shaping raised beds into rows spaced $1 \mathrm{~m}$ apart. These preparatory procedures are typical practices for chile pepper in southern New Mexico. A schedule of major field operations is presented in Table 1.

Treatments AND EXPERIMENTAL DESIGN. For this study, a false seedbed refers to the combination of irrigation and subsequent shallow tillage that ended weed seedlings. There were 14 $\mathrm{d}$ between the false seedbed irrigation and the subsequent tillage. Irrigation water was groundwater obtained with a $210-\mathrm{V}$ electric pump. Irrigation water was applied so that areas between raised beds were flooded (surface water depth, 3 inches) and raised beds were saturated. False seedbed tillage was one pass with a four-row, tractor-operated rolling cultivator (Bowman, 2002) that disturbed the upper 2 inches of soil across furrows and raised beds.

Treatments differed in the number of false seedbeds implemented the summer before chile pepper planting. Treatments were zero false seedbeds, two false seedbeds, and three false seedbeds. Treatments were arranged in a randomized complete block design with four replications. Experimental units were plots with four raised beds, $30 \mathrm{~m}$ in length. For the two false seedbed treatment in experimental run 1 , irrigations took place on 27 July and 13 Aug. For the three false seedbed treatment in experimental run 1, irrigations occurred 27 July, 13 Aug., and 16 Sept. During experimental run 2 , irrigations occurred 28 July and 23 Aug. for the two false seedbed treatment. For the three false seedbed treatment in experimental run 2, irrigations occurred 28 July, 23 Aug., and 28 Sept.

FIELD OPERATIONS DURING CHILE PEPPER SEASONS. 'NM 6-4' chile pepper was seeded into raised beds at 6 $\mathrm{lb} / \mathrm{acre}$ to a depth of $\mathrm{l}$ inch using a mechanical planter (MaxEmerge Plus; John Deere, Moline, IL). Shortly after crop seeding and before crop emergence, a residual herbicide (napropamide at $\mathrm{l} \mathrm{lb} / \mathrm{acre}$ ) was applied to soil for preemergence control of small-seeded broadleaf and grass weeds. Napropamide was incorporated into soil with irrigation that occurred within $4 \mathrm{~h}$ of herbicide application. Subsequent weed control in chile pepper was accomplished with combinations of cultivations, hand hoeing, and applications of an herbicide that controlled emerged grass weeds (clethodim at $2 \mathrm{oz} /$ acre). 
Table 1. Schedule of main activities for a field study that determined the effects of false seedbeds on chile pepper production. The study took place at the New Mexico State University, Leyendecker Plant Science Research Center, Las Cruces, NM (lat. $32.19^{\circ} \mathrm{N}$, long. $\left.106.74^{\circ} \mathrm{W}\right)$.

\begin{tabular}{llcc}
\hline Study period & Activity & Experimental run 1 & Experimental run 2 \\
\hline False seedbed & Installation of raised beds & 25 July 2015 & 13 July 2016 \\
& Irrigation for false seedbed 1 & 27 July 2015 & 28 July 2016 \\
& Irrigation for false seedbed 2 & 13 Aug. 2015 & 23 Aug. 2016 \\
& Irrigation for false seedbed 3 & 16 Sept. 2015 & 28 Sept. 2016 \\
Chile pepper & Chile pepper seeding & 26 Apr. 2016 & 18 Apr. 2017 \\
& Timed hoeing & 2 June 2016 & 19 May 2017 \\
& & 20 June 2016 & 5uly 2017 \\
& & 22 July 2016 Aug. 2017 & 28 Aug. 2017 \\
& & 15 Aug. 2016 & 9 Sept. 2017 \\
& Green fruit harvest & 9 Sept. 2016 & 24 Oct. 2017 \\
\hline
\end{tabular}

Nitrogen ( $\mathrm{N}$ ) fertilizer was applied through irrigation water. For experimental run $1, \mathrm{~N}$ fertilizer was applied at $70 \mathrm{lb} /$ acre at 7 weeks after crop seeding. For experimental run $2, \mathrm{~N}$ fertilizer was applied at $70 \mathrm{lb} /$ acre split in two applications at 7 and 12 weeks after crop seeding. At 9 weeks after seeding, chile pepper plants were thinned to clumps (three to five plants per clump) spaced 7 inches apart.

Data collection. Experimental units were sectioned to create three permanent locations for repeatedly collecting data on weed density during false seedbed and chile pepper seasons. Sub-sampling locations were positioned in a central row that was parallel the longitudinal axes of experimental units. Adjacent sub-sampling locations were spaced $7 \mathrm{~m}$ apart. At each sub-sampling location and before all weed control interventions, weed seedlings were identified to species and removed with minimal soil disturbance from $0.25-\mathrm{m}^{2}$ quadrats. Quadrats were initially placed in furrows and on beds; however, preliminary data analyses indicated that weed densities did not differ between furrows and beds. For succinctness, weed densities are presented for furrows only.

The amount of time required for one individual to hand hoe two, $10-\mathrm{m}^{2}$ sections of crop row was determined for each hoeing intervention that occurred during chile pepper seasons. Hoers were student research technicians, not professional laborers, assigned to a replicate within a run. At the conclusion of each chile pepper season, hoeing time data were summed to determine cumulative hoeing time for each experimental unit. To use hoeing time data in economic analyses, these data were scaled to an acre.

Fresh weights of marketable fruit were determined for green fruit on 9 Sept. 2016 and 7 Sept. 2017, and red fruit on 24 Oct. 2016 and 3 Oct. 2017. Green and red fruit were harvested by hand from separate 6-m sections of crop row. Marketable fruit were straight, free of disease symptoms and blemishes, and at least 4 inches in length.

ECONOMIC COST-BENEFIT ANALYsIs. Cost-benefit analyses were conducted separately for each experimental run. False seedbed implementation costs were determined using 2016 and 2017 NMSU Crop Enterprise Budgets for Doña Ana County, NM (Hawkes and Libbin, 2019). These enterprise budgets were developed, and updated annually, by panels of extension economists, producers, and experts familiar with the specific production system and cropping region.

Implementing a false seedbed involved two component costs: 1) irrigation, which included expenses for labor and pump operation, valued at $\$ 4.31 /$ acre for each irrigation event and 2) mechanical cultivation, which included expenses for labor and tractor operation, valued at $\$ 6.56 /$ acre for each cultivation event. The overall cost for implementing a false seedbed treatment was $\$ 10.87 /$ acre Costs for hand hoeing involved an hourly rate set to the local minimum wage at the time the study was conducted $(\$ 7.50 / \mathrm{h})$ plus taxes (social security, $6.2 \%$ and workers compensation, $6.3 \%$ ), which produced a laborer wage rate of $\$ 8.54 / \mathrm{h}$. This hourly wage was multiplied by the mean cumulative hoeing time for each treatment within a run. The resulting product was the annual per acre hoeing expense for a specific treatment. Savings derived from false seedbeds were determined as

$$
S=H C_{\text {withoutfs }}-\left(H C_{\text {withfs }}+I C_{f s}\right)
$$

where $S=$ savings incurred from false seedbeds, $H C_{\text {withoutfs }}=$ hoeing expense without false seedbeds, $H C_{\text {withfs }}=$ hoeing expense with false seedbeds, and $I C_{f s}=$ false seedbed implementation cost.

For each treatment, green fruit yield means were converted to tons per acre and multiplied by the per ton monetary values in NMSU Crop Enterprise Budgets for Doña Ana County, NM (Hawkes and Libbin, 2019). These budgets indicated that green fruit were worth $\$ 490.00$ / ton in 2016 and $\$ 475.00 /$ ton in 2017. For red fruit, NMSU Crop Enterprise Budgets provide per pound monetary values for dried fruit. The moisture content standard for dried red chile pepper fruit is $10 \%$, whereas freshly picked red fruit are $80 \%$ water (Walker, 2011). Accordingly, in this study, fresh weights for red chile pepper fruit were reduced by $70 \%$. Then, red fruit yield means were multiplied by per pound monetary values for dried red fruit in NMSU Crop Enterprise Budgets $(\$ 0.73 / \mathrm{lb}$ in 2016 , $\$ 0.60 / \mathrm{lb}$ in 2017) (Hawkes and Libbin, 2019). To determine revenue after hoeing costs for green and red chile pepper fruit produced with and without false seedbeds, hoeing 
expenses were subtracted from per acre gross profits. Harvesting expenses were not considered in the analysis.

Data analysis. Data were analyzed using the AOV function in the open source statistical software program R version 3.6.2 (R Development Core Team, 2019). The primary objective for this study was to determine the economic consequences of false seedbeds using, in part, monetary values that differed between years. Accordingly, experimental runs were analyzed separately. Date-specific and cumulative data for weed density and hoeing time were analyzed separately using analysis of variance (ANOVA) followed by Tukey's honestly significant difference tests. To meet ANOVA assumptions of constant error variance, weed density and hoeing time data were log-transformed. On occasions when weed density data included zero values, data were transformed with $\log (x+$ 1). Chile pepper fruit yield data were analyzed using ANOVAs followed by
Tukey's honestly significant difference tests.

\section{Results}

ENVIRONMENTAL CONDITIONS AND WEED COMMUNITIES. Conditions were favorable for the emergence of summer annual weeds during both false seedbed seasons. During false seedbeds of experimental run 1 , mean daily air temperature was $26.1^{\circ} \mathrm{C}$; and during false seedbeds of experimental run 2 , mean daily air temperature was $23.9^{\circ} \mathrm{C}$. For chile pepper growing seasons, conditions were generally conducive to chile pepper growth (mean daily air temperature was $23.5^{\circ} \mathrm{C}$ during experimental run 1 , $23.9^{\circ} \mathrm{C}$ during experimental run 2 ); however, growing seasons differed in total precipitation. During the chile pepper season of experimental run 1 , total precipitation was $12.2 \mathrm{~cm}$, whereas total precipitation was 17.8 $\mathrm{cm}$ during the chile pepper season of experimental run 2. Precipitation differences between experimental growing seasons were greatest during July. During July of experimental run 1, the study site received $0.53 \mathrm{~cm}$ of rain. During July of experimental run 2 , the study site received $11.0 \mathrm{~cm}$ of rain. The high amount of rain in July of experimental run 2 prevented laborers from entering the field during this period. Notable differences in precipitation between experimental runs also occurred when chile pepper plants were at cotyledon to four-leaf stages ( 14 to $40 \mathrm{~d}$ after crop seeding). During this period in experimental run 1 , the study site received 0.56 $\mathrm{cm}$ of rain, whereas during the chile pepper establishment period in experimental run 2, the study site did not receive precipitation.

Experimental runs differed with respect to the density, timing, and composition of the weeds that emerged during false seedbed and chile pepper growing seasons (Table $2)$. During experimental run 1 , the weed community was dominated by the annual grasses junglerice (Echinochloa colona) and yellow foxtail (Setaria pumila). More than 7000 weeds emerged from permanent quadrats during the first experimental run,

Table 2. Cumulative densities for weed species that emerged during false seedbeds and chile pepper growing seasons. False seedbeds were sequences of irrigation and tillage that eliminated weed seedlings before crop planting. For experimental run 1 (Run 1), false seedbeds were implemented July 2015 to Sept. 2015 and chile pepper was grown Apr. 2016 to Oct. 2016. For experimental run 2 (Run 2), false seedbeds were implemented July 2016 to Sept. 2016 and chile pepper was grown Apr. 2017 to Oct. 2017. Data are sums across all experimental units $(\mathrm{N}=12)$. Each experimental unit contained permanent quadrats in which weeds were repeatedly counted and removed with minimal soil disturbance.

\begin{tabular}{|c|c|c|c|c|}
\hline \multirow[b]{2}{*}{ Study period } & \multicolumn{2}{|c|}{ Species } & \multirow{2}{*}{\multicolumn{2}{|c|}{$\frac{\text { Run 1 }}{\text { Seedlings }}\left[\right.$ no. $/ \mathrm{m}^{2}\left(\frac{\text { Run } 2}{(\% \text { total })]^{\mathrm{z}}}\right.$}} \\
\hline & Common name & Scientific name & & \\
\hline \multirow[t]{6}{*}{ False seedbed } & Grass species ${ }^{y}$ & Poaceae & $4,021(95.3 \%)^{x}$ & $1,773(40.6 \%)$ \\
\hline & Palmer amaranth & Amaranthus palmeri & $38(<1.0 \%)$ & $171(3.9 \%)$ \\
\hline & Spurred anoda & Anoda cristata & $4(<1.0 \%)$ & $516(11.8 \%)$ \\
\hline & Tall morningglory & Ipomoea purpurea & $-\mathrm{w}$ & $277(6.3 \%)$ \\
\hline & Ground spurge & Euphorbia humistrata & $3(<1.0 \%)$ & - \\
\hline & False seedbed season total & & 4,222 & 4,370 \\
\hline \multirow[t]{5}{*}{ Chile pepper } & Grass species ${ }^{y}$ & Poaceae & $2,672(93.8 \%)$ & $760(43.6 \%)$ \\
\hline & Wright groundcherry & P. acutifolia & $89(3.1 \%)$ & $604(34.7 \%)$ \\
\hline & Common purslane & P. oleracea & $4(<1.0 \%)$ & $5(<1.0 \%)$ \\
\hline & Ground spurge & E. humistrata & - & $7(<1.0 \%)$ \\
\hline & Chile pepper season total & & 2,848 & 1,743 \\
\hline Overall total & & & 7,070 & 6,113 \\
\hline
\end{tabular}

${ }^{\mathrm{z}} 1$ seedling $/ \mathrm{m}^{2}=0.8361$ seedling $/$ yard $^{2}$.

${ }^{\mathrm{y}}$ Mixture of junglerice (Echinochloa colona) and yellow foxtail (Setaria pumila).

${ }^{\mathrm{x}}$ Parentheses present percentages of totals with periods.

"Dashed lines indicate that the species was not present. 

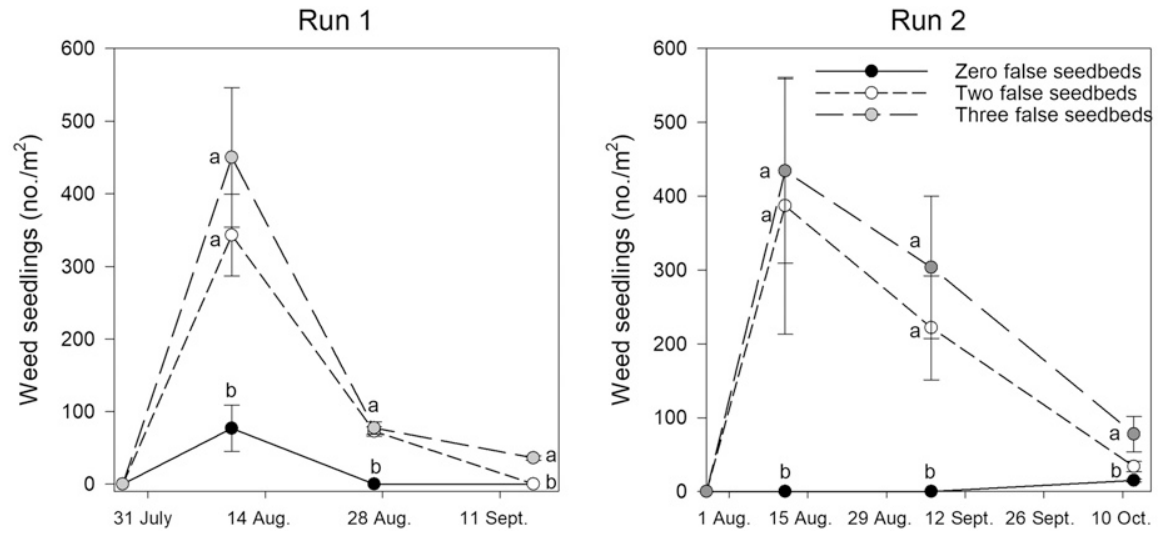

Fig. 1. Weed seedling densities during false seedbeds of experimental run 1 (Run 1 ) in 2015 and experimental run 2 (Run 2) in 2016. False seedbeds were sequential combinations of irrigation and tillage. Tillage, which occurred 14 $\mathrm{d}$ after irrigation, eliminated all weed seedlings. Just before tillage, weed seedling densities were determined. False seedbed treatments differed in number of iterations. For the two false seedbed treatment in Run 1, irrigations took place on 27 July and 13 Aug. For the three false seedbed treatment in Run 1, irrigations occurred 27 July, 13 Aug., and 16 Sept. For the two false seedbed treatment in Run 2, irrigations occurred 28 July and 23 Aug. For the three false seedbed treatment in Run 2, irrigations occurred 28 July, 23 Aug., and 28 Sept. Data points are means with SE $(\mathrm{N}=4)$. Means within a date that share the same letter are not different according to Tukey's honestly significant difference tests at $\boldsymbol{P}<0.05$; 1 seedling $/ \mathrm{m}^{2}=0.8361$ seedling $/$ yard $^{2}$.

with $40 \%$ of these weeds emerging during the chile pepper season. Compared against experimental run 1 , experimental run 2 featured an abundance of broadleaf weeds, and a greater proportion of the total weeds emerged during false seedbeds. Further, the chile pepper season in experimental run 2 had 39\% less weeds, and $72 \%$ less grass weeds, than the season in experimental run 1 . Differences between experimental runs in weed pressure corresponded with variability in initial weed seedbank density. At the onsets of false seedbed seasons, plots in experimental run 2 featured, on average, 73\% fewer weed seeds in soil than plots in experimental run 1 (Sanchez, 2018).

FALSE SEEDBED EFFECTS ON WEED SEEDLING EMERGENCE AND HAND HOEING. False seedbed treatments influenced the total number of weed seedlings that emerged during the false seedbed season of experimental run $1\left(F_{2,6}=11.14, P=0.009\right)$ and experimental run $2\left(F_{2,6}=21.84, P=\right.$ $0.002)$. More seedlings emerged in the two and three false seedbed treatments compared with the zero false seedbed treatment (Fig. 1). Post hoc tests indicated that increasing the number of false seedbeds from two to three did not affect the total number of weed seedlings that emerged during the false seedbed season of experimental run $1(P=$ $0.65)$ or experimental run $2(P=$ 0.64 ), although the third irrigation for the three false seedbed treatment caused some additional emergence compared with the two false seedbed treatment (Fig. 1).

During both cropping seasons, weed seedling densities did not differ between the two false seedbed treatment and the three false seedbed treatment $(P \geq 0.05$ for all observation dates). Furthermore, there was no difference between the two and three false seedbed treatments in $\mathrm{cu}^{-}$ mulative hoeing time (experimental run $1, P=0.98$; experimental run 2 , $P=0.97$ ), green fruit yield (experimental run $1, P=0.39$; experimental run $2, P=0.97)$, or red fruit yield (experimental run $1, P=0.96$; experimental run 2, $P=0.94)$. Considering the absence of significant difference between the two and three false seedbed treatments, data from the two and three false seedbed treatments were combined to create a single treatment, with two and three false seedbeds treated as sub-samples.

Chile pepper with false seedbeds had fewer weeds than chile pepper without false seedbeds during experimental run 1 (Fig. 2). During experimental run 2 , false seedbeds did not reduce weed seedling densities during the chile pepper season. Despite the irregularity between runs in false seedbed effects on weed densities, false seedbeds reduced hoeing time in both experimental run 1 and experimental run 2 (Table $3)$. For experimental run 1 , false seedbeds reduced hoeing time for three of the four hoeing interventions. For experimental run 2 , false seedbeds reduced hoeing time on 8 Aug., but not on 19 May, 5 July, and 28 Aug. Cumulative hoeing time was reduced $45 \%$ by false seedbeds during experimental run 1. During experimental run 2 , false seedbeds caused a $24 \%$ reduction in cumulative hoeing time. False seedbed-induced reductions in hoeing times provided economic benefits because false seedbed implementation costs (\$21.74/acre for two false seedbeds, $\$ 32.61 /$ acre for three false seedbeds) were small compared with hand hoeing costs in the absence of false seedbeds. Compared with chile pepper without false seedbeds and considering implementation costs, false seedbeds reduced expenses for hand hoeing by $\$ 262.43 /$ acre to $\$ 440.41$ /acre (Table 4).

FALSE SEEDBED EFFECTS ON CHILE PEPPER. Visual assessments of crop performance indicated that chile pepper plants were stunted in false seedbed plots early in the growing season of experimental run 1 . These visual assessments were confirmed with height measurements of 20 chile pepper plants in each plot on 20 June 2016 [mean $( \pm \mathrm{SE})$ height for chile pepper plants with false seedbeds, $11.9 \pm 0.34 \mathrm{~cm}$; mean height for chile pepper plants without false seedbeds, $17.2 \pm 1.35 \mathrm{~cm}]$. Young chile pepper plants in false seedbed plots may have been injured by soil salts that splashed during rain, or strong winds, in late May. In plots without false seedbeds, salt splash or wind did not injure young chile pepper plants because these plants were shielded by weeds (Supplemental Fig. 1). Stunting of chile pepper plants was not likely caused by mineral nutrient deficiencies or soil salinization because false seedbeds did not influence soil fertility or soil electrical conductivity (EC) at the time of chile pepper seeding (Supplemental Table 1). By 
Table 3. Hoeing times for chile pepper with and without false seedbeds. Data are means of four replications. Summaries for analysis of variance $F$ tests present false seedbed effects on hoeing time for the specific date or cumulative total.

\begin{tabular}{|c|c|c|c|c|c|c|c|c|c|c|}
\hline \multirow[b]{4}{*}{ Treatment } & \multicolumn{10}{|c|}{ Hoeing time } \\
\hline & \multicolumn{5}{|c|}{ Experimental run 1} & \multicolumn{5}{|c|}{ Experimental run 2} \\
\hline & 2 June & 20 June & 22 July & 15 Aug. & $\begin{array}{c}\text { Cumulative } \\
\text { total }\end{array}$ & 19 May & 5 July & 8 Aug. & 28 Aug. & $\begin{array}{c}\text { Cumulative } \\
\text { total }\end{array}$ \\
\hline & \multicolumn{10}{|c|}{$\left(\min / 10 \mathrm{~m}^{2}\right)^{\mathrm{z}}$} \\
\hline $\begin{array}{l}\text { Without false } \\
\text { seedbeds }\end{array}$ & 6.01 & 1.35 & 4.57 & 6.06 & 17.99 & 4.71 & 4.93 & 8.44 & 3.63 & 21.71 \\
\hline$F$-test & $\begin{array}{c}F_{1,3}= \\
11.46, \\
P=0.04\end{array}$ & $\begin{array}{c}F_{1,3}= \\
2.64 \\
P=0.20\end{array}$ & $\begin{array}{c}F_{1,3}= \\
13.71, \\
P=0.03\end{array}$ & $\begin{array}{c}F_{1,3}= \\
21.58 \\
P=0.02\end{array}$ & $\begin{aligned} F_{1,3} & =15.04 \\
P & =0.03\end{aligned}$ & $\begin{array}{c}F_{1,3}= \\
4.51 \\
P=0.12\end{array}$ & $\begin{array}{c}F_{1,3}= \\
1.13, \\
P=0.37\end{array}$ & $\begin{array}{c}F_{1,3}= \\
32.06 \\
P=0.01\end{array}$ & $\begin{array}{c}F_{1,3}= \\
1.23, \\
P=0.35\end{array}$ & $\begin{aligned} F_{1,3} & =10.05 \\
P & =0.05\end{aligned}$ \\
\hline
\end{tabular}

${ }^{\mathrm{z}} 1 \mathrm{~min} / 10 \mathrm{~m}^{2}\left(12.0 \operatorname{yard}^{2}\right)=0.0836 \mathrm{~min} / \mathrm{yard}^{2}$.

Table 4. Cost-benefit analyses for false seedbeds implemented before chile pepper. Savings incurred from false seedbeds were determined from false seedbed-induced reductions in hoeing expense, with consideration of false seedbed implementation cost.

\begin{tabular}{|c|c|c|c|c|c|}
\hline \multirow[b]{3}{*}{ Treatment } & \multirow[b]{2}{*}{ False seedbed $\operatorname{cost}^{\mathrm{z}}$} & \multicolumn{2}{|c|}{$\begin{array}{l}\text { Hoeing expenses in } \\
\text { chile pepper }\end{array}$} & \multicolumn{2}{|c|}{ Savings from false seedbed ${ }^{w}$} \\
\hline & & Run 1 & Run 2 & Run 1 & Run 2 \\
\hline & \multicolumn{5}{|c|}{$(\$ / \text { acre })^{y}$} \\
\hline Without false seedbed & - & 1,037 & 1,251 & - & - \\
\hline With false seedbed & 21.74 to 32.61 & 574 & 956 & 430 to 440 & 262 to 273 \\
\hline \multicolumn{6}{|c|}{$\begin{array}{l}\left.\left.{ }^{z} \text { Cost for implementing false seedbeds included two component costs: } 1\right) \text { irrigation expenses valued at } \$ 4.31 / \text { acre per irrigation, and } 2\right) \text { cultivation expenses valued at } \$ 6.56 / \\
\text { acre per cultivation. The overall cost for implementing a false seedbed was } \$ 10.87 / \text { acre. } \\
\text { implementation costs were from Hawkes and Libbin }(2019) \text {. } \\
\text { ' } \$ 1 / \text { acre }=\$ 2.4711 / \text { ha. } \\
{ }^{x} \text { Cost for hand hoeing involved an hourly rate set to the local minimum wage at the time the study was conducted }(\$ 7.50 / \mathrm{h}) \text { plus taxes, which produced a laborer wage rate of } \\
\$ 8.54 / \mathrm{h} \text {. This hourly wage was multiplied by the mean cumulative hoe time for each treatment within a run: experimental run } 1(\mathrm{Run} 1) \text { and experimental run } 2(\text { Run } 2) \text {. } \\
\text { w } S=H C_{w i t h o u t f s}-\left(H C_{w i t h f s}+I C_{f s}\right) \text {, where } S=\text { savings incurred from false seedbeds, } H C_{w i t h o u t f s}=\text { hoeing expense without false seedbeds, } H C_{w i t h f s}=\text { hoeing expense with false } \\
\text { seedbeds, and } I C_{f s}=\text { false seedbed implementation cost. }\end{array}$} \\
\hline
\end{tabular}

midsummer, chile pepper plants in false seedbed plots no longer appeared stunted. This observation was confirmed with height measurements of 20 chile pepper plants in each plot on 4 Aug. 2016 [mean $( \pm$ SE) height for chile pepper plants with false seedbeds, $65.9 \pm 1.15 \mathrm{~cm}$; mean height for chile plants without false seedbeds, $66.5 \pm 2.07 \mathrm{~cm}]$. For experimental run 2 , visual assessments indicated no difference in chile pepper plant performance between false seedbed treatments. The lack of stunting in experimental run $2 \mathrm{co}^{-}$ incided with the absence of rainfall early in the growing season, which further suggests that rain in late May contributed to chile pepper stunting in false seedbed plots during experimental run 1 .

For experimental run 1, green fruit yield was lower for chile pepper with false seedbeds compared with chile pepper without false seedbeds (Table 5). Decreased green fruit yield for chile pepper with false seedbeds resulted in gross profit losses that were not offset by false seedbed-induced reductions in hoeing costs. Accordingly, profit after deduction of hoeing expenses was higher for chile pepper without false seedbeds compared with chile pepper with false seedbeds for experimental run 1 . For experimental run 2, false seedbeds were associated with nonsignificant increases in green fruit yield. These nominal increases in yield, combined with reductions in hoeing costs, meant that false seedbeds increased profits for green fruit when compared with chile pepper without false seedbeds.

Red fruit yield was not significantly affected by false seedbed treatment during experimental run 1 or experimental run 2 (Table 6). Nominal increases in red fruit yield, combined with reductions in hoeing expense, led to higher red fruit profits for chile pepper with false seedbeds when compared with chile pepper without false seedbeds. For red fruit, false seedbeds increased net profits by $11 \%$ in experimental run 1 , and by $23 \%$ for experimental run 2 .

\section{Discussion}

This study was conducted to evaluate false seedbeds for chile pepper production in New Mexico. Because labor costs and availability are primary constraints on profitable chile pepper production in New Mexico (Hawkes et al., 2008), emphasis was placed on false seedbed effects on labor requirements for weeding.

The results of this study indicated that false seedbeds decreased hoeing times in chile pepper, which was consistent with a previous study that determined stale seedbeds reduced hoeing times in lettuce [ $\mathrm{Lac}^{-}$ tuca sativa (Shem-Tov et al., 2006)]. In experimental run 1 , false seedbed-induced reductions in hoeing time followed false seedbed-induced decreases in weed density. However, for experimental run 2, decreases in hoeing time caused by 
false seedbeds did not coincide with reduced weed densities. This result suggests that diminished weed densities were not required for reductions in hoe time. In general, labor requirements for weeding are influenced by densities of targeted weed infestations (Melander and Rasmussen, 2001; Sutton et al., 2006), and sizes and locations of weeds to be removed (Kelly et al., 2007). Thus, in experimental run 2 , higher hoeing times for chile pepper without false seedbeds may have been caused by larger weeds or weeds in closer proximity to the crop, as compared with the sizes and locations of weeds in chile pepper with false seedbeds.
In this study, two procedural actions were intended to intensify seedbank reductions caused by false seedbeds. First, false seedbeds were implemented with three iterations. Second, false seedbeds were conducted when seeds of problematic weed species were expected to be germinable and minimally dormant. Results indicated that the first of these two actions was unnecessary because increasing the number of false seedbeds from two to three did not increase the total number of weed seedlings that emerged before crop planting. However, the second action for intensifying false seedbed effects on seedbanks was likely necessary because conducting false or stale
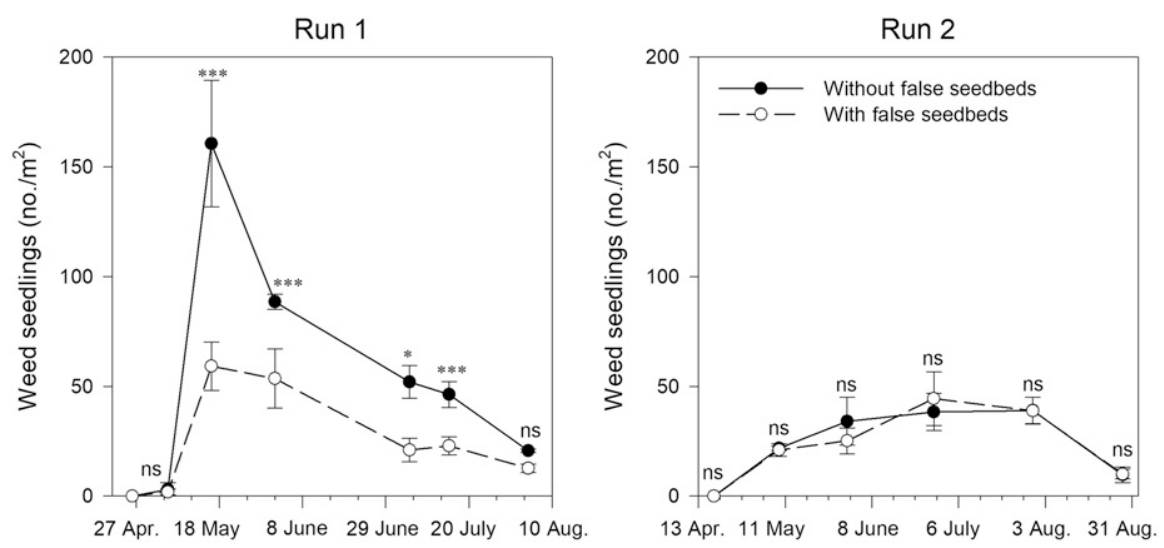

Fig. 2. Weed seedling densities in chile pepper grown with and without false seedbeds in experimental run 1 (Run 1 ) in 2016 and experimental run 2 (Run 2) in 2017. False seedbeds were sequential combinations of irrigation and tillage that eliminated weed seedlings before crop planting. For Run 1, false seedbeds were implemented July 2015 to Sept. 2015. For Run 2, false seedbeds were implemented July 2016 to Sept. 2016. Data points are means with SE $(N=4)$ and represent the number of weeds counted and removed from permanent quadrats. Symbols above data points indicate results from analysis of variance $F$ tests, with ${ }^{*} P<0.05,{ }^{*}{ }^{*} P<0.001$, and $\mathrm{ns}=$ no significant effect; 1 seedling $/ \mathrm{m}^{2}=0.8361$ seedling/ yard $^{2}$. seedbeds when weed seeds are germinable is essential to efficacy (Boyd et al., 2006). Problematic weeds in chile pepper-including wright groundcherry (Physalis acutifolia), palmer amaranth (Amaranthus palmeri), and spurred anoda (Anoda cristata) - typically do not emerge during the conventional period for chile pepper seedbed preparation (i.e., February, March), even if soil is wetted. This is because germination of problematic weeds in chile pepper is thought to require soil temperatures greater than those that are normal for February or March in southern New Mexico (BenechArnold et al., 2000). Therefore, false or stale seedbeds for chile pepper are likely to be maximally effective if they are conducted when soil is warmer than soil during February or March. False or stale seedbeds the summer or fall before chile pepper planting can be incorporated into crop rotations that feature chile pepper after crops typically harvested in summer. In New Mexico, such crops include, but are not limited to, barley (Hordeum vulgare), wheat (Triticum aestivum), and onion (Allium cepa), which are harvested in early summer.

The recommended timing for false seedbeds for chile pepper differs from stale seedbed recommendations for other vegetable crops. For lettuce, Shem-Tov et al. (2006) recommended stale seedbeds $14 \mathrm{~d}$ before planting. For cucumber (Cucumis sativus), Lonsbary et al. (2003) recommended stale seedbeds 20 to $30 \mathrm{~d}$ before planting. Stale seedbeds for spinach (Spinacia oleracea) were implemented 6 and $13 \mathrm{~d}$ before crop seeding (Fontanelli et al., 2015). Compared

Table 5. Green fruit yield for chile pepper in 2016 (experimental run 1) and 2017 (experimental run 2) with and without false seedbeds. Data are means of four replications. Mean yields were used to determine per acre gross profits and profits after deduction of hoeing expenses.

\begin{tabular}{|c|c|c|c|c|c|c|}
\hline \multirow[b]{3}{*}{ Treatment } & \multicolumn{3}{|c|}{ Experimental run 1} & \multicolumn{3}{|c|}{ Experimental run 2} \\
\hline & \multirow{2}{*}{$\begin{array}{l}\text { Yield }^{\mathrm{z}} \\
(\mathrm{kg} / \\
\left.6 \mathrm{~m}^{2}\right)^{\mathrm{y}}\end{array}$} & $\begin{array}{l}\text { Gross } \\
\text { profit }^{x}\end{array}$ & $\begin{array}{l}\text { Profit after hoeing } \\
\text { expense }^{\mathrm{w}}\end{array}$ & \multirow{2}{*}{$\begin{array}{l}\text { Yield } \\
(\mathrm{kg} / \\
\left.6 \mathrm{~m}^{2}\right)\end{array}$} & $\begin{array}{l}\text { Gross } \\
\text { profit }\end{array}$ & $\begin{array}{c}\text { Profit after hoeing } \\
\text { expense }\end{array}$ \\
\hline & & \multicolumn{2}{|r|}{$(\$ / \text { acre })^{y}$} & & \multicolumn{2}{|r|}{ (\$/acre) } \\
\hline $\begin{array}{l}\text { Without false } \\
\text { seedbeds }\end{array}$ & $16.2 \mathrm{a}^{\mathrm{v}}$ & 5,903 & 4,866 & $19.8 \mathrm{a}$ & 6,994 & 5,743 \\
\hline With false seedbeds & $13.0 \mathrm{~b}$ & 4,737 & 4,162 & $22.4 \mathrm{a}$ & 7,912 & 6,956 \\
\hline
\end{tabular}

${ }^{\mathrm{z}}$ Fresh weight of marketable green fruit.

${ }^{\mathrm{y}} 1 \mathrm{~kg} / 6 \mathrm{~m}^{2}\left(7.2\right.$ yard $\left.^{2}\right)=0.3072 \mathrm{lb} /$ yard $^{2}, \$ 1 /$ acre $=\$ 2.471 \mathrm{l} / \mathrm{ha}$.

${ }^{\mathrm{x}}$ Green chile pepper fruit grown in the study region returned $\$ 490.00 /$ ton in 2016 and $\$ 475.00 /$ ton in 2017 (Hawkes and Libbin, 2019 ); $\$ 1 /$ ton $=\$ 1.1023 / \mathrm{Mg}$.

${ }^{\mathrm{w}}$ Cost for hand hoeing involved an hourly rate set to the local minimum wage at the time the study was conducted $(\$ 7.50 / \mathrm{h})$ plus taxes, which produced a laborer wage rate of $\$ 8.54 / \mathrm{h}$. This hourly wage was multiplied by the mean cumulative hoe time for each treatment within a run. Further information on hoeing expenses is reported in Table 4 . ${ }^{\mathrm{v}}$ Means within a column followed by the same letter are not significantly different according to analysis of variance at $P=0.05$. 
Table 6. Red fruit yield for chile pepper in 2016 (experimental run 1) and 2017 (experimental run 2) with and without false seedbeds. Data are means of four replications. Mean yields were used to determine per acre gross profits and profits after deduction of hoeing expenses.

\begin{tabular}{|c|c|c|c|c|c|c|}
\hline \multirow[b]{3}{*}{ Treatment } & \multicolumn{3}{|c|}{ Experimental run 1} & \multicolumn{3}{|c|}{ Experimental run 2} \\
\hline & Yield ${ }^{\mathrm{z}}$ & $\begin{array}{l}\text { Gross } \\
\text { profit }^{\mathrm{x}}\end{array}$ & $\begin{array}{c}\text { Profit after hoeing } \\
\text { expense }^{w}\end{array}$ & Yield & $\begin{array}{l}\text { Gross } \\
\text { profit }\end{array}$ & $\begin{array}{c}\text { Profit after hoeing } \\
\text { expense }\end{array}$ \\
\hline & $\begin{array}{c}(\mathrm{kg} / \\
\left.6 \mathrm{~m}^{2}\right)^{\mathrm{y}}\end{array}$ & & $(\$ / \text { acre })^{\mathrm{y}}$ & $\begin{array}{l}(\mathrm{kg} / \\
\left.6 \mathrm{~m}^{2}\right)\end{array}$ & & $(\$ /$ acre $)$ \\
\hline $\begin{array}{l}\text { Without false } \\
\text { seedbeds }\end{array}$ & $21.2 \mathrm{a}^{\mathrm{v}}$ & 6,905 & 5,868 & $18.2 \mathrm{a}$ & 4,872 & 3,621 \\
\hline
\end{tabular}

${ }^{\mathrm{z}}$ Fresh weight of marketable red fruit.

${ }^{y} 1 \mathrm{~kg} / 6 \mathrm{~m}^{2}\left(7.2 \operatorname{yard}^{2}\right)=0.3072 \mathrm{lb} /$ yard $^{2}, \$ 1 /$ acre $=\$ 2.4711 / \mathrm{ha}$.

${ }^{\mathrm{x}}$ Returns for red fruit were determined by first converting fresh weights of marketable red fruit to the weight of fruit suitable for dry storage. Dried fruit yield data were then multiplied by the monetary values indicated in New Mexico State University Crop Enterprise Budgets, which were \$0.73/lb in 2016 and $\$ 0.60 / \mathrm{lb}$ in 2017 (Hawkes and Libbin, 2019); $\$ 1 / \mathrm{lb}=\$ 2.2046 / \mathrm{kg}$.

${ }^{\mathrm{w}}$ Cost for hand hoeing involved an hourly rate set to the local minimum wage at the time the study was conducted $(\$ 7.50 / \mathrm{h})$ plus taxes, which produced a laborer wage rate of $\$ 8.54 / \mathrm{h}$. This hourly wage was multiplied by the mean cumulative hoe time for each treatment within a run. Further information on hoeing expenses is reported in Table 4 . ${ }^{v}$ Means within a column followed by the same letter are not significantly different according to analysis of variance at $P=0.05$.

with lettuce, cucumber, and spinach, the chile pepper features a longer growing season. Lettuce is harvestable 70 to $76 \mathrm{~d}$ after seeding (ShemTov et al., 2006), harvest maturity for cucumber is 44 to $50 \mathrm{~d}$ after seeding (Lonsbary et al., 2003), and spinach can be harvested $60 \mathrm{~d}$ after seeding (Fontanelli et al., 2015). Chile pepper requires at least 120 to $165 \mathrm{~d}$ from seeding to harvest (Bosland and Walker, 2014). Differences in growing season length among lettuce, cucumber, and chile pepper coincide with differences in durations for critical periods for weed control. For lettuce, the critical period for weed control is about the first 28 d after crop emergence (Fennimore et al., 2014). For cucumber, the critical period for weed control concludes 24 to $36 \mathrm{~d}$ after crop emergence (Friesen, 1978). But, for chile pepper, the critical period for weed control concludes $\approx 103 \mathrm{~d}$ after transplanting (AmadorRamirez, 2002) and is likely longer than $103 \mathrm{~d}$ in direct-seeded chile pepper (Tursun et al., 2012).

Shorter growing seasons means that environmental conditions shortly before crop seeding may match conditions after crop seeding to a greater degree than pre- and post-plant conditions for a crop with a longer growing season. For example, long-term average climate data for the study region and planting dates in ShemTov et al. (2006) indicate the daily mean temperatures typically increase $1.4^{\circ} \mathrm{C}$ from $14 \mathrm{~d}$ before crop seeding to the midpoint of the lettuce growing season (36 d after crop seeding) [U.S. Department of Commerce, National Oceanic and Atmospheric
Administration (NOAA), 2020]. For the region and planting dates in this study, long-term average climate data indicate that daily mean temperatures typically increase $12.7^{\circ} \mathrm{C}$ from $14 \mathrm{~d}$ before crop seeding to the midpoint of the chile pepper growing season (87 d after crop seeding) (NOAA, 2020). With a longer growing season and lower degree of similarity between conditions shortly before crop seeding and after crop seeding, chile pepper is likely to benefit minimally from false or stale seedbed schedules for short-season vegetables.

Unlike a previous study that reported stale seedbeds did not affect cotton (Gossypium hirsutum) plant height and yield (Dogan et al., 2009), the results from this study suggest that false seedbeds can create conditions that are injurious to young chile pepper plants. However, it is important to note that false seedbeds did not result in soil EC greater than $1.5 \mathrm{mmho} / \mathrm{cm}$, which is both an EC threshold above which chile pepper plant growth is impeded (Maas and Hoffman, 1977) and an indicator of worsening conditions for vegetable production under low rainfall and high temperatures. If young chile pepper plants are stunted after false seedbeds, the results of this study suggests that stunting is temporary and inconsequential for red fruit yield. Accordingly, growers who suspect that false seedbeds inhibited chile pepper growth should consider growing for red pepper markets rather than green pepper markets, if possible.
Also, growers seeking reductions in labor requirements for weeding can consider stale seedbeds instead of false seedbeds. Stale seedbeds eliminate weeds that emerge before cashcrop planting, with herbicides or propane flamers instead of shallow tillage (Cloutier et al., 2007). Because stale seedbeds leave ended weeds on the soil surface, stale seedbeds might create a physical barrier that prevents crop injury from salt splash or strong winds that can occur early in the growing season.

\section{Conclusions}

After accounting for costs for implementation, false seedbeds were projected to reduce hand hoeing costs by $\$ 262 /$ acre to $\$ 440 /$ acre. Such savings may exemplify best-case scenarios because the student research technicians who hoed weeds in this study might have been less efficient than professional laborers. Nonetheless, this study indicated that false seedbeds implemented the summer before planting are a means for reducing labor requirements for weeding in chile pepper. The results of this study suggest that two false seedbeds are sufficient for suppressing hand hoeing costs in chile pepper. However, more information is needed on the relationships among false seedbed frequency, false seedbed irrigation volume, and false seedbedderived benefits. This information will lead to technical guidance that allows growers in New Mexico to implement false seedbeds in manners mindful of regional needs for water conservation. 


\section{Literature cited}

Amador-Ramirez, M.D. 2002. Critical period of weed control in transplanted chilli pepper. Weed Res. 42:203-209.

Benech-Arnold, R.L., R.A. Sanchez, F. Forcella, B.C. Kruk, and C.M. Ghersa. 2000. Environmental control of dormancy in weed seed banks in soil. Field Crops Res. 67:105-122, doi: 10.1016/s03784290(00)00087-3.

Bosland, P.W. 2015. The history, development, and importance of the New Mexican pod-type chile pepper to the United States and world food industry. Plant Breed. Rev. 39:283-324.

Bosland, P.W. and S.J. Walker. 2014. Growing chiles in New Mexico. New Mexico State Univ. Coop. Ext. Serv. Guide H-230.

Bowman, G. 2002. Steel in the filed: A farmer's guide to weed management tools. Sustainable Agriculture Network, Beltsville, MD.

Boyd, N.S., E.B. Brennan, and S.A. Fennimore. 2006. Stale seedbed techniques for organic vegetable production. Weed Technol. 20:1052-1057, doi: 10.1614/ wt-05-109.1.

Caldwell, B. and C.L. Mohler. 2001. Stale seedbed practices for vegetable production. HortScience 36:703-705, doi: 10.21273/hortsci.36.4.703.

Chen, G.H., L. Kolb, A. Leslie, and C.R.R. Hooks. 2017. Using reduced tillage and cover crop residue to manage weeds in organic vegetable production. Weed Technol. 31:557-573, doi: 10.1017/ wet.2017.24.

Cloutier, D.C., R.Y. van der Weide, A. Peruzzi, and M.L. Leblanc. 2007. Mechanical weed managment, p. 111-134, In: M.K. Upadhyaya and R.E. Blackshaw (eds.). Non-chemical weed management: Principles, concepts and technology. CAB Intl., Cambridge, MA.

Davis, A.S. and M.M. Williams. 2007. Variation in wild proso millet (Panicum miliaceum) fecundity in sweet corn has residual effects in snap bean. Weed Sci. 55:502-507, doi: 10.1614/ws-07-046.1.

Dieleman, J.A., D.A. Mortensen, and A.R. Martin. 1999. Influence of velvetleaf (Abutilon theophrasti) and common sunflower (Helianthus annums) density variation on weed management outcomes. Weed Sci. 47:81-89, doi: 10.1017/ s004317450009069x.

Dogan, M.N., A. Unay, O. Boz, and D. Oguet. 2009. Effect of pre-sowing and pre-emergence glyphosate applications on weeds in stale seedbed cotton. Crop Prot.
28:503-507, doi: 10.1016/j.cropro.2009. 01.013

Fennimore, S.A., R. Smith, S. Dara, and H.S. Agamalian. 2014. Lettuce (Lactuca sativa), p. 295-298. In: S.A. Fennimore and C.E. Bell (eds.). Principles of weed control. 4th ed. California Weed Sci. Soc., Salinas, CA.

Fontanelli, M., L. Martelloni, M. Raffaelli, C. Frasconi, M. Ginanni, and A. Peruzzi. 2015. Weed management in autumn fresh market spinach: A nonchemical alternative. HortTechnology 25:177-184, doi: 10.21273/horttech. 25.2.177.

Friesen, G.H. 1978. Weed interference in pickling cucumbers (Cucumis sativus). Weed Sci. 26:626-628.

Gandonou, J.M. and T.M. Waliczek. 2013. An analysis of the recent trends in U.S. chile pepper production, consumption and imports. J. Food Agr. Environ. 11:361-367.

Hartzler, R.G. and G.W. Roth. 1993. Effect of prior years weed control on herbicide effectiveness in corn (Zea mays). Weed Technol. 7:611-614.

Hawkes, J. and J.D. Libbin. 2019. Cost and return estimates for farms and ranches 2013-2019. 1 July 2020. <https://aces. nmsu.edu/cropcosts/>.

Hawkes, J., J.D. Libbin, and B.A. Jones. 2008. Chile production in New Mexico and northern Mexico. J. Amer. Soc. Farm Manag. Rural Appraisers 71:83-92.

Islam, M.N., A.M. Baltazar, S.K. De Datta, and A. Karim. 2009. Management of purple nutsedge (Cyperus rotundus L.) tuber populations in rice-onion cropping systems. Philipp. Agr. Sci. 92:407-418.

Johnson, W.C. and B.G. Mullinix. 1995. Weed management in peanut using stale seedbed techniques. Weed Sci. 43:293297, doi: $10.1017 / s 0043174500081200$.

Johnson, W.C. and B.G. Mullinix. 1998. Stale seedbed weed control in cucumber. Weed Sci. 46:698-702, doi: 10.1017/ s0043174500089736.

Kelly, M.J., M.P. Pritts, and R.R. Bellinder. 2007. Evaluation of new cultivation tools to reduce labor requirements in matted-row strawberry culture. HortTechnology 17:87-94, doi: 10.21273/ horttech.17.1.87.

Lee, R.D. and J. Schroeder. 1995. Weed management in chile. New Mexico State Univ. Agr. Expt. Sta. Circ. 548.

Lonsbary, S.K., J. O'Sullivan, and C.J. Swanton. 2003. Stale-seedbed as a weed management alternative for machineharvested cucumbers (Cucumis satious).
Weed Technol. 17:724-730, doi: 10.1614/ wt02-123.

Maas, E.V. and G.J. Hoffman. 1977. Crop salt tolernace-Current assessment. Amer. Soc. Civil Eng. J. Irrig. Drain. Div. 103:115-134.

Melander, B. and G. Rasmussen. 2001. Effects of cultural methods and physical weed control on intrarow weed numbers, manual weeding and marketable yield in direct-sown leek and bulb onion. Weed Res. 41:491-508, doi: 10.1046/j.13653180.2001.00252.x.

R Development Core Team. 2019. R: A language and environment for statistical computing. R Foundation for Statistical Computing, Vienna, Austria.

Riemens, M.M., R.M.W. Groeneveld, L.A.P. Lotz, and M.J. Kropff. 2007. Effects of three management strategies on the seedbank, emergence and the need for hand weeding in an organic arable cropping system. Weed Res. 47:442-451, doi: 10.1111/j.1365-3180.2007.00582.x.

Sanchez, A.D. 2018. Use of stale seedbeds for summer annual weeds in chile. MS Thesis, New Mexico State Univ., Las Cruces.

Sanogo, S., B.F. Etarock, and M. Clary. 2009. Recovery of Verticillium dabliae from tall morningglory (Ipomoea purpurea) in New Mexico and its pathogenicity on chile pepper. Plant Dis. 93:428, doi: 10.1094/pdis-93-4-0428a.

Sanogo, S., J. Schroeder, S. Thomas, L. Murray, N. Schmidt, J. Beacham, C. Fiore, and L. Liess. 2013. Weed species not impaired by Verticillium dabliae and Meloidogyne incognita relationships that damage chile pepper. Plant Health Prog. 14:8.

Schroeder, J. 1992. Oxyfluorfen for directed postemergence weed control in chile peppers (Capsicum annuиm). Weed Technol. 6:1010-1014.

Schroeder, J. 1993. Late-season interference of spurred anoda in chile peppers. Weed Sci. 41:172-179, doi: 10.1017/ s0043174500076025.

Schutte, B.J. and A. Cunningham. 2015. Tall morningglory (Ipomoea purpurea) seedbank density effects on pendimethalin control outcomes. Weed Technol. 29:844-853, doi: 10.1614/wt-d-1400161.1

Shem-Tov, S., S.A. Fennimore, and W.T. Lanini. 2006. Weed management in lettuce (Lactuca sativa) with preplant irrigation. Weed Technol. 20:1058-1065, doi: 10.1614/wt-05-085.1.

Sutton, K.F., W.T. Lanini, J.P. Mitchell, E.M. Miyao, and A. Shrestha. 2006. 
Weed control, yield, and quality of processing tomato production under different irrigation, tillage, and herbicide systems. Weed Technol. 20:831-838, doi: 10.1614/wt-05-057.1.

Swanton, C.J., K.J. Mahoney, K. Chandler, and R.H. Gulden. 2008. Integrated weed management: Knowledge-based weed management systems. Weed Sci. 56:168-172, doi: 10.1614/ws-07126.1.

Tursun, N., I.E. Akinci, A. Uludag, Z. Pamukoglu, and D. Gozcu. 2012. Critical period for weed control in direct seeded red pepper (Capsicum annum L.). Weed Biol. Mgt. 12:109-115, doi: 10.1111/ j.1445-6664.2012.00441.x.

U.S. Department of Agriculture, National Agricultural Statistics Service (USDANASS). 2020. Survey of peppers, chileAcres planted and production. 20 Nov. 2020. <https://quickstats.nass.usda. $\operatorname{gov} />$.

U.S. Department of Commerce, National Oceanic and Atmospheric Administration
(NOAA). 2020. 1981-2010 Climate normals. 20 Nov. 2020. <https://www. ncdc.noaa.gov/cdo-web/datatools/ normals $>$.

Walker, S.J. 2011. Postharvest handling of dehydrated chiles. New Mexico State Univ. Coop. Ext. Serv. Guide H-236. 
Supplemental Table 1. False seedbed effects on soil fertility just before chile pepper seeding. Soil samples were taken by collecting 30 cores [ 1 inch $(2.5 \mathrm{~cm})$ diameter, $10 \mathrm{~cm}$ (3.9 inches) depth] in a W-shaped pattern across an experimental unit. Cores from each experimental unit were pooled, mixed, and analyzed by a commercial laboratory (A\&L Plains Agricultural Laboratories, Lubbock, TX). Fields differed between experimental runs and were located at the New Mexico State University, Leyendecker Plant Science Research Center, Las Cruces, NM (lat. 32.19 ${ }^{\circ} \mathrm{N}$, long. 106.74 ${ }^{\circ} \mathrm{W}$ ). Data are means of four replications, unless noted otherwise. Within a column, means were not significantly different based on analysis of variance $(\alpha=0.05)$.

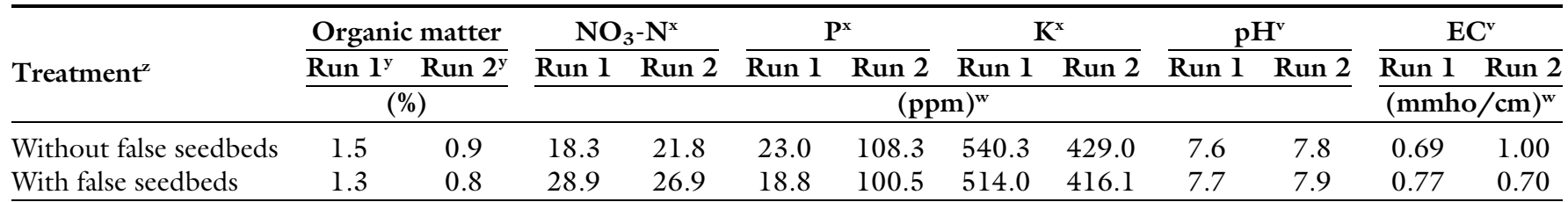

${ }^{\mathrm{z}}$ False seedbeds were implemented twice or thrice before chile pepper seeding. The number of false seedbed iterations did not influence soil properties $(P \geq 0.05$ for all soil properties). Accordingly, data from the two and three false seedbed treatments were combined to create a single treatment, with two and three false seedbeds treated as subsamples.

${ }^{y}$ Experimental run 1 (Run 1) began in July 2015 and ended in Oct. 2016. Experimental run 2 (Run 2) began in July 2016 and ended in Oct. 2017 . Run 1 analyses used only three replications because a sample bag broke during shipping.

${ }^{x}$ Nitrate-nitrogen $\left(\mathrm{NO}_{3}-\mathrm{N}\right)$, phosphorus $(\mathrm{P})$, potassium $(\mathrm{K})$.

${ }^{\mathrm{w}} 1 \mathrm{ppm}=1 \mathrm{mg} \cdot \mathrm{kg}^{-1}, 1 \mathrm{mmho} / \mathrm{cm}=1 \mathrm{mS} \cdot \mathrm{cm}^{-1}$.

${ }^{\mathrm{v}} \mathrm{Soil} \mathrm{pH}$ and electrical conductivity (EC) from saturated paste. 

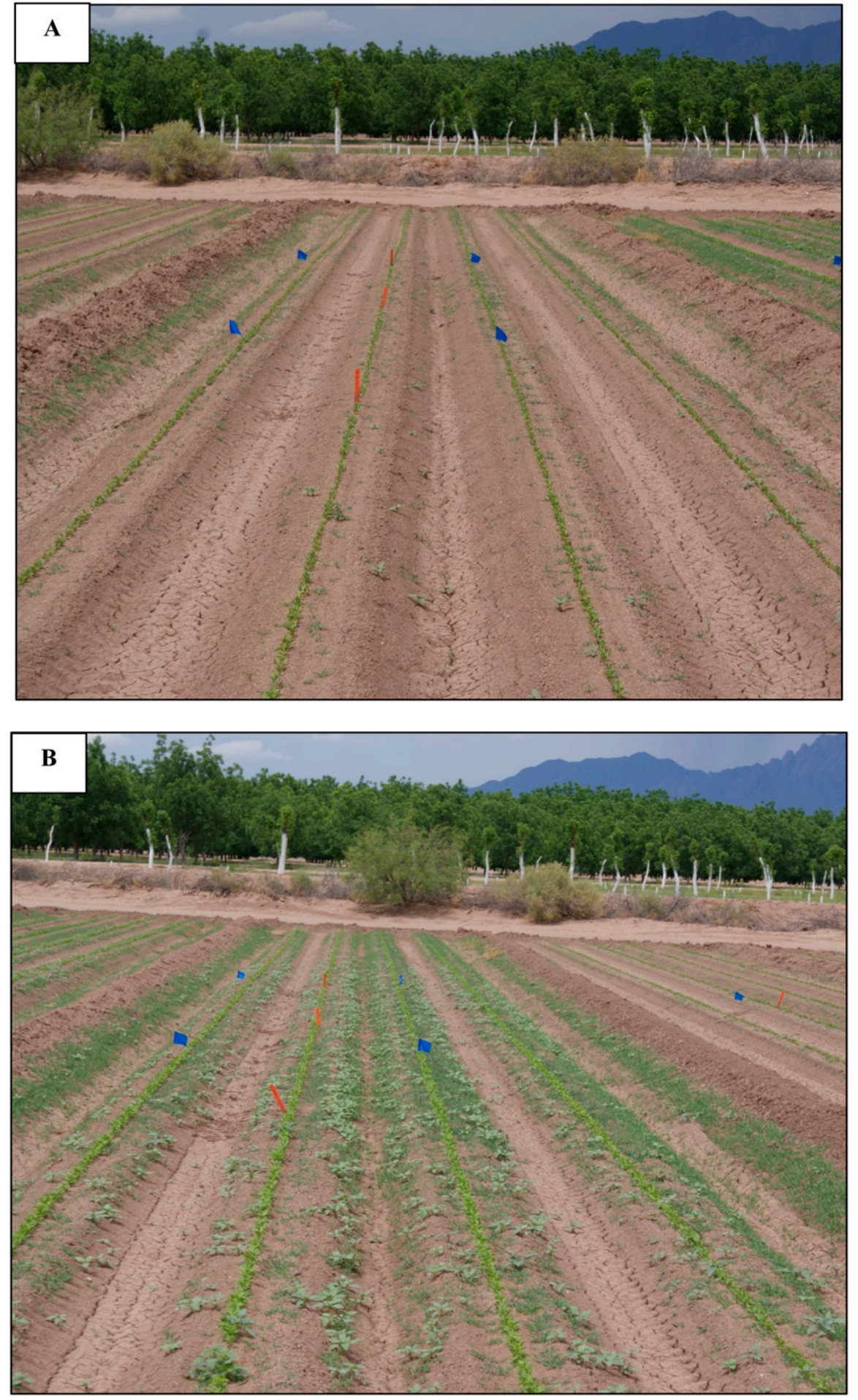

Supplemental Fig. 1. Images of experimental units on 1 June 2016. Treatments shown are chile pepper with false seedbeds (A) and chile pepper without false seedbeds (B). 